\title{
Carotenoid Compounds in Grapes and Their Relationship to Plant Water Status
}

\author{
C. Oliveira,$^{\dagger}$ A. C. Silva Ferreira,${ }^{\dagger}$ M. Mendes Pinto, ${ }^{\dagger}$ T. HogG, ${ }^{\dagger}$ \\ F. Alves,$\ddagger$ AND P. Guedes DE PINHO $*, \dagger$
}

Escola Superior de Biotecnologia, Universidade Católica Portuguesa, R. Dr. António Bernardino de Almeida, 4200-072 Porto, Portugal, and ADVID, Associação para o Desenvolvimento da Viticultura Duriense, R. José Vasques Osório 62, 5ª Apt 137, 5050-280 Peso da Régua, Portugal

\begin{abstract}
The aim of this work was to study the relationship between carotenoid contents in grapevine berries and plant water status. For this purpose, a black grapevine variety, Vitis vinifera L. cv. Touriga Nacional, was studied. The experiments were carried out in the same Douro vineyards, with plants of the same age, in two different water retention soils. A higher water retention capacity soil, soil A, and a lower water retention capacity soil, soil $B$, were both in a $1.2 \mathrm{~m}$ deep silt-loam schist-derived soil. The training system was the double cordon trained and spur pruned. A first range was nonirrigated (NI) and a second one was irrigated (I), $60 \%$ of evapotranspiration (ET $)$. For soil $\mathrm{B}$, a $30 \%$ of $\mathrm{ET}_{0}$ treatment was also applied. The plant water status was estimated by predawn leaf water potential. The effects of plant water status on berry growth were studied by measurement of the berry weight and total soluble solids ( ${ }^{\circ}$ Brix). The carotenoid profile was quantitatively determined by high-performance liquid chromatography/diode array. Carotenoids determined were $\beta$-carotene, lutein, neoxanthin, violaxanthin, and luteoxanthin. The comparison between irrigated and nonirrigated grapes was followed from 2 weeks before veraison until the ripe stage. Results showed that at harvest time, berries exposed to the $\mathrm{NI}$ had a lower weight than those exposed to the irrigated treatment $\left(60 \%\right.$ of $\left.E \mathrm{~T}_{0}\right), 0.89$ vs 1.36 g/berry and 0.94 vs $1.34 \mathrm{~g} /$ berry, for soils A and B, respectively. The irrigated treatment contributed to a higher sugar concentration in both soils. However, depending on the soil water retention capacity, the carotenoid contents were different in soils A and B. For soil A, the total carotenoid content was similar for both $\mathrm{NI}$ and I treatments. However, with regard to soil B, in irrigated treatment, levels of carotenoids were approximately $60 \%$ lower than those found for the NI. It seems to be possible to produce higher weight berries (with higher sugar levels) with similar carotenoid contents. On the other hand, soil characteristics had a larger influence than irrigation on the concentration of carotenoids in grapes, resulting in an important viticultural parameter to take into account in aroma precursor formation.
\end{abstract}

KEYWORDS: Vitis vinifera; carotenoids; plant water status; irrigation; berry growth

\section{INTRODUCTION}

The presence of carotenoids in grapes is well-documented, having been demonstrated that $\beta$-carotene and some xanthophylls (neoxanthin, flavoxanthin, and lutein) are abundant before veraison, and subsequently decreasing dramatically $(1-3)$. Three other xanthophylls, namely, violaxanthin, luteoxanthin, and 5,6epoxylutein, appear after veraison, when the sugar concentration reaches approximately $160 \mathrm{~g} / \mathrm{L}$ (3). Cultivar, viticultural region, exposure to sunlight, and ripening stage all affect carotenoid concentrations in grapes (4-7). Carotenoids are known as precursors of $\mathrm{C} 13$-norisoprenoid compounds $(8,9)$, which have

* To whom correspondence should be addressed. Tel: +351225580095 Fax: +351225580088. E-mail: pinho@esb.ucp.pt.

†niversidade Católica Portuguesa.

$\doteqdot$ ADVID. been identified in grapes and wines and are known to be responsible for the typical aroma of some varieties.

The effect of irrigation on berry composition $\left({ }^{\circ}\right.$ Brix, glucose, fructose, $\mathrm{pH}$, organic acids, mineral elements, and phenolic content), color, and weight (g/berry) has been reported by many authors $(10-15)$. It is reported that sugar content increases when irrigation is applied during the ripening stage, while irrigation during the early stages of berry development brings about an increase in grape yield together with a decrease in sugar concentration (10). Recent studies have indicated that weight (g/berry), ${ }^{\circ}$ Brix, and glucose and fructose concentrations are significantly higher in Is than NIs $(11,12)$. This fact could be related to a higher vegetative growth (I) resulting in higher pruning weights and a higher leaf area index, where irrigated vines are not exposed to heat stress as compared to nonirrigated 
Table 1. Definition of Soil Type, Irrigation Regime, and Climatic Conditions for Elemental Plots ${ }^{a}$

\begin{tabular}{|c|c|c|c|c|c|}
\hline plot code & ANI & Al $60 \%$ & $\mathrm{BNI}$ & BI $60 \%$ & $\mathrm{BI} 30 \%$ \\
\hline soil & soil type A & soil type A & soil type B & soil type B & soil type B \\
\hline irrigation regime & $\mathrm{NI}$ & $60 \%$ of $\mathrm{ET}_{0}$ & $\mathrm{NI}$ & $60 \%$ of $E T_{0}$ & $30 \%$ of $\mathrm{ET}_{0}$ \\
\hline training system & DCSP & DCSP & DCSP & DCSP & DCSP \\
\hline vine spacing & $2.2 \mathrm{~m} \times 1.0 \mathrm{~m}$ & $2.2 \mathrm{~m} \times 1.0 \mathrm{~m}$ & $2.2 \mathrm{~m} \times 1.0 \mathrm{~m}$ & $2.2 \mathrm{~m} \times 1.0 \mathrm{~m}$ & $2.2 \mathrm{~m} \times 1.0 \mathrm{~m}$ \\
\hline vines per hectare & 4500 & 4500 & 4500 & 4500 & \\
\hline rainfall (mm) (June-Sept) & 107.6 & 107.6 & 107.6 & 107.6 & 107.6 \\
\hline average temp $\left({ }^{\circ} \mathrm{C}\right)$ (June-Sept) & 23.5 & 23.5 & 23.5 & 23.5 & 23.5 \\
\hline $\mathrm{ET}_{0}(\mathrm{~mm})$ (June-Aug) & 380 & 380 & 380 & 380 & 380 \\
\hline water applied (mm) & 0 & 240 & 0 & 240 & 120 \\
\hline
\end{tabular}

a Soil type A, high water retention capacity soil: initially escavated to $1.2 \mathrm{~m}$ depth with the base rock (schist) at approximately $0.8 \mathrm{~m}$ deep. The stoniness of this soil is approximately $40 \%$. Soil type B, low water retention capacity soil: initially excavated to $1.2 \mathrm{~m}$ depth with the base rock (schist) at approximately $0.4 \mathrm{~m}$ deep. The stoniness of this soil is approximately $80 \%$. DCSP, double cordon and spur pruned.

Table 2. Data Used for Carotenoid Identification in Grape Berries

\begin{tabular}{|c|c|c|c|c|c|c|c|c|}
\hline \multirow[b]{2}{*}{ pigment identified } & \multirow[b]{2}{*}{$\operatorname{tr}(\mathrm{HPLC})$} & \multicolumn{6}{|c|}{ spectral data, $\lambda_{\max }(\mathrm{nm})$} & \multirow[b]{2}{*}{ source of pigment } \\
\hline & & \multicolumn{3}{|c|}{ HPLC solvent } & \multicolumn{3}{|c|}{ ethanol } & \\
\hline neoxanthin & 5.5 & 415 & 438 & 466 & 415 & 438 & 467 & CaroteNature \\
\hline violaxanthin & 6.0 & 418 & 441 & 471 & 420 & 441 & 471 & CaroteNature \\
\hline luteoxanthin & 6.2 & 400 & 422 & 448 & & & & \\
\hline lutein & 13.6 & (422) & 447 & 476 & (421) & 446 & 475 & Sigma (alfalfa) \\
\hline IS ( $\beta$-apo-8'-carotenal) & 18.8 & & 460 & & 464 & & & Fluka \\
\hline chlorophyll a & 30.2 & & 410 & & & & & Aldrich (spinach) \\
\hline$\beta$-carotene & 32.4 & (428) & 454 & 482 & & & & Sigma \\
\hline
\end{tabular}

vines that suffer high temperatures (12). The organic acids (tartaric acid, malic acid, and citric acid) are present in high concentrations in green grapes and begin to decrease at veraison (12). The rate of decrease is greater for malic acid than for tartaric acid, and this difference is greatest in NIs (12). Medium or severe water deficits, occurring in the early stages of growth, have significant effects on cell size but not on cell division (13), while water deficit levels occurring during the period from veraison to maturity stimulate phenolic biosynthesis $(13-15)$.

The aroma potential during ripening, caused by moderate irrigation, showed higher values for Is (16). The relationship between carotenoid contents in grapevine berries and plant water status has not yet been established. The aim of this present study was to examine the relationship between carotenoid content in grapevine berries and plant water status. For this purpose a black grapevine variety, Vitis vinifera L. cv. Touriga Nacional, was studied during the 2 weeks before veraison until full ripeness. The effects of plant water status on berry growth were studied by measuring the berry weight and ${ }^{\circ}$ Brix, and the carotenoid profile was quantitatively determined by high-performance liquid chromatography (HPLC)/diode array.

\section{MATERIALS AND METHODS}

Plant Material. This experiment was conducted during 1 year (2002) with the variety Vitis vinifera L. cv. Touriga Nacional. Vines were 6 years old and were planted with 196-17 rootstock in the same vineyard plot in the Douro Superior subregion of northern Portugal.

Soils Types, Irrigation, and Sampling. Samples were taken from vines segregated into elemental plots (45 vines each) defined in terms of soil type and irrigation regime. The sampling period was from 2 weeks prior to veraison until full ripeness (19/07, 22/08, 4/09, and 19/ 09). All plots can be considered equal in terms of vine training system, plant density, and climatic conditions (Table 1). The $\mathrm{ET}_{0}$ was estimated by the Penman-Monteith method as described by Allen et al. (17). The irrigation period was from $14 / 06$ till $19 / 09$. ${ }^{\circ}$ Brix was measured using a refractometer LEICA-model 7530.
Extraction and Determination of Carotenoids. Grape Material. Approximately $50 \mathrm{~g}$ of fresh berries, of seeds, were homogenized using a Turrax homogenizer at $9500 \mathrm{rpm}$ for $15 \mathrm{~min}$. This procedure provided $40 \mathrm{~g}$ of sample that was spiked with $200 \mu \mathrm{L}$ of internal standard and $170 \mathrm{mg} / \mathrm{L}$ of $\beta$-apo- $8^{\prime}$-carotenal (Fluka, Portugal) (10810) and was diluted with $40 \mathrm{~mL}$ of water $(18.3 \mathrm{M} \Omega / \mathrm{cm})$. Extraction was carried out with $40 \mathrm{~mL}$ of ether/hexane $(1: 1, \mathrm{v} / \mathrm{v})$, HPLC grade (MERCK, Portugal), and agitated for $30 \mathrm{~min}$. The extraction was repeated two more times with $20 \mathrm{~mL}$ of ether/hexane $(30 \mathrm{~min}$ each). The final combined extract was concentrated to dryness (rotavapor) and resuspended in $1 \mathrm{~mL}$ of acetone/hexane $(1: 1, \mathrm{v} / \mathrm{v})$ for HPLC determination. Light exposure was minimized during sample preparations in order to avoid photoisomerization.

HPLC. A Beckman model 126 quaternary solvent system, equipped with a System 32 Karat software and a 168 rapid-scanning, UV-visible photodiode array detector, was used. The absorption spectra were recorded between 270 and $550 \mathrm{~nm}$.

Stationary Phase. Nova-Pack C18 $60 \AA 4 \mu \mathrm{m}$ particles $(3.9 \times 300$ $\mathrm{mm})$, Waters.

Mobile Phase. Solvent A, ethyl acetate (Merck pure grade); solvent $\mathrm{B}$, acetonitrile/water $(9: 1 \mathrm{v} / \mathrm{v})$ (Merck pure grade and pure water); flow rate $=1 \mathrm{~mL} / \mathrm{min}$. The following gradient was employed, $0-31 \mathrm{~min}$ $(0-60 \%$ A); $31-46 \min (60 \%$ A $) ; 46-51 \min (60-100 \%$ A); $51-55$ $\min \left(100 \%\right.$ A); 55-60 min (100-0\% A); 60-65 min $\left(0 \%\right.$ A). $R_{\mathrm{t}}$ values: neoxanthin (5.5 min), violaxanthin (6.0 min), luteoxanthin (6.2 $\mathrm{min})$, lutein (13.6 min), unknown (27.5 $\mathrm{min})$, chlorophyll (30.2 $\mathrm{min})$, and $\beta$-carotene (32.4 $\mathrm{min})$ (18).

Identification. Carotenoids were identified by comparison with commercially available standards, $\beta$-carotene (Sigma 95\%, synthetic) (C-9750), lutein (Sigma 70\%, from alfalfa) (X-6250), neoxanthin (0234.1) and violaxanthin (0259) from (CaroteNature $\mathrm{GmbH}$ from Switzerland), and chlorophyll a (Aldrich, from spinach) (25 825-3). Luteoxanthin was identified by comparison of retention time and UVvisible photodiode array spectra (Table 2 and Figure 1).

Statistical Analysis. Principal component analysis (PCA) and cluster analysis (dendogram) were carried out using a XLSTAT-Pro version 6.1.8. The PCA method shows similarities between samples projected on a plane and makes it possible to determine which variables determine 


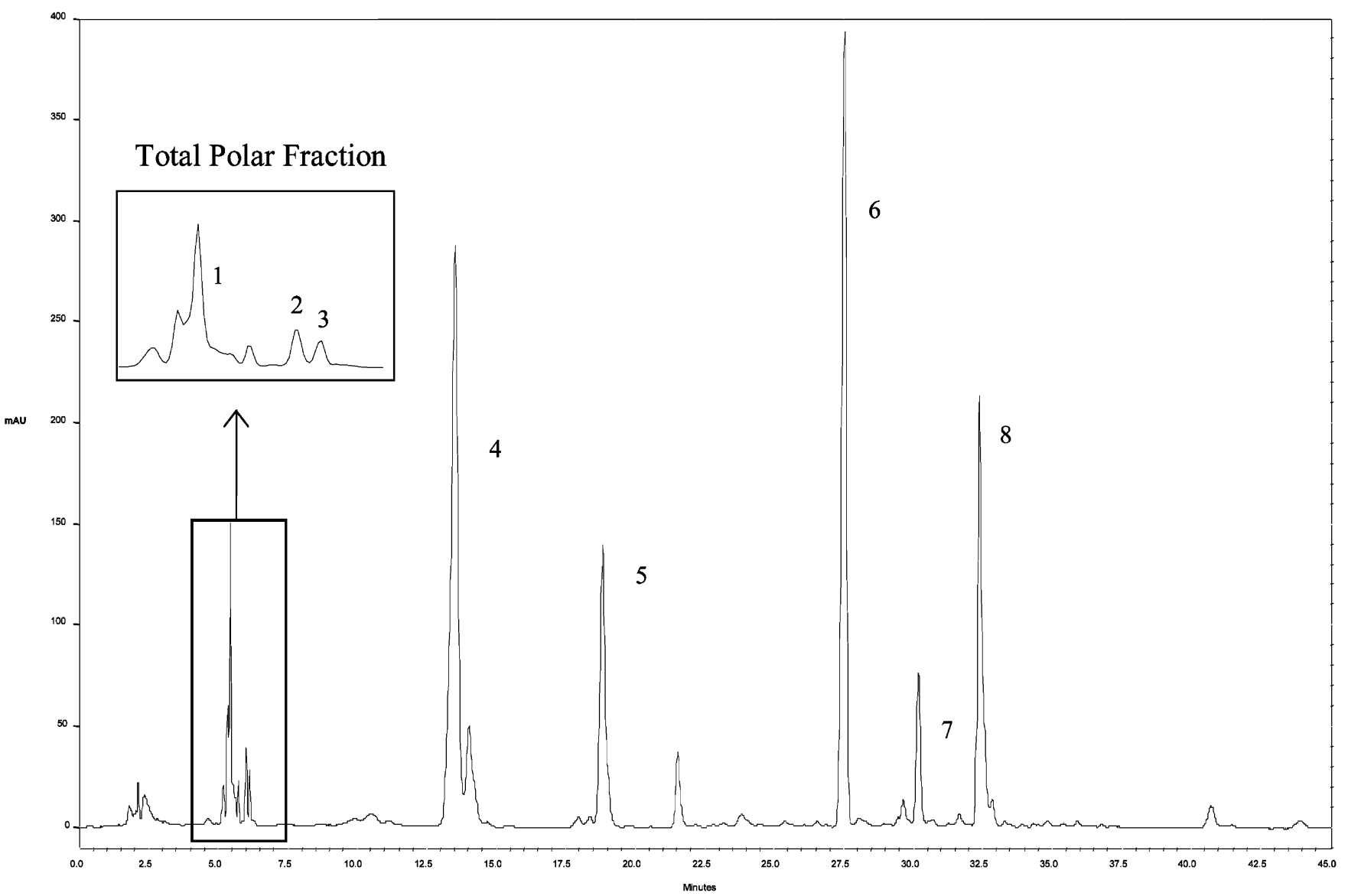

Figure 1. HPLC chromatogram of carotenoids of Touriga Nacional from BNI grapes at harvest time (19/09). DO = $447 \mathrm{~nm}$. (1) Neoxanthin, (2) violaxanthin, (3) luteoxanthin, (4) lutein, (5) internal standard, (6) unknown, (7) chlorophyll $a$, and (8) $\beta$-carotene.

Table 3. Changes in Carotenoid Contents of the Grape Berries Harvested from Different Soils with and without Irrigation during Ripeninga

\begin{tabular}{|c|c|c|c|c|c|c|c|c|}
\hline plot code & neoxanthin & violaxanthin & luteoxanthin & lutein & chlorophyll a & carotene & weight/berry & ${ }^{\circ}$ Brix \\
\hline ANI_I & 66 & 0 & 0 & 1183 & 327 & 1981 & 0.48 & 6 \\
\hline ANI_II & 92 & 22 & 2 & 929 & 163 & 1363 & 0.88 & 15 \\
\hline ANI_III & 70 & 23 & 1 & 571 & 90 & 918 & 0.90 & 17 \\
\hline ANI_IV & 85 & 12 & 0 & 624 & 93 & 1046 & 0.89 & 17 \\
\hline Al $60 \overline{\%}$ _l & 115 & 0 & 0 & 1499 & 334 & 2153 & 0.56 & 5 \\
\hline Al $60 \%$ _ll & 71 & 16 & 2 & 548 & 94 & 764 & 1.56 & 18 \\
\hline Al $60 \%$ _III & 65 & 23 & 2 & 519 & 80 & 746 & 1.52 & 22 \\
\hline Al 60\%_IV & 164 & 27 & 4 & 874 & 121 & 1204 & 1.36 & 25 \\
\hline BNI_I & 65 & 0 & 0 & 1563 & 360 & 2018 & 0.50 & 6 \\
\hline BNI_II & 49 & 6 & 1 & 514 & 89 & 739 & 0.94 & 16 \\
\hline BNI_III & 63 & 7 & 2 & 452 & 67 & 677 & 0.95 & 19 \\
\hline BNI_IV & 98 & 26 & 17 & 728 & 116 & 1102 & 0.94 & 19 \\
\hline BI 30\%_l & 33 & 0 & 0 & 881 & 198 & 1198 & 0.57 & 6 \\
\hline BI 30\%_II & 39 & 1 & 1 & 340 & 55 & 448 & 1.39 & 21 \\
\hline BI 30\%_III & 41 & 10 & 4 & 260 & 38 & 369 & 1.26 & 23 \\
\hline BI $30 \%$ _IV & 32 & 6 & 1 & 152 & 21 & 238 & 1.02 & 24 \\
\hline Bl 60\%_l & 44 & 0 & 0 & 855 & 194 & 999 & 0.54 & 5 \\
\hline BI $60 \%$ _ll & 94 & 4 & 1 & 615 & 110 & 721 & 1.42 & 19 \\
\hline Bl 60\%_III & 84 & 17 & 0 & 629 & 93 & 762 & 1.20 & 23 \\
\hline Bl 60\%_IV & 57 & 9 & 0 & 282 & 40 & 356 & 1.34 & 26 \\
\hline
\end{tabular}

${ }^{a}$, sample data for 19/07; II, sample data for 22/08; III, sample data for 04/09; IV, sample data for 19/09. Carotenoid concentration is expressed in $\mu \mathrm{g} / \mathrm{kg}$ of berry. Neoxanthin, violaxanthin, and luteoxanthin are expressed in equivalents of lutein. Berry weight is in grams.

these similarities and in what way. The dendogram method shows correlations by clusters diagrams.

\section{RESULTS AND DISCUSSION}

The effect of irrigation on changes in carotenoid contents for soil A and soil B is shown in Table 3. The comparison was made from 2 weeks before veraison, during ripening, and at harvest time $(19 / 07,22 / 08,4 / 09$, and 19/09). Carotenoids analyzed were $\beta$-carotene, lutein, neoxanthin, violaxanthin, and luteoxanthin. Chlorophyll $a$ was also considered due to its major impact during grape ripening, as an indicator of maturation. Results showed that from all plots and experimentation, carotenoid content decreased during ripening with a concomitant 


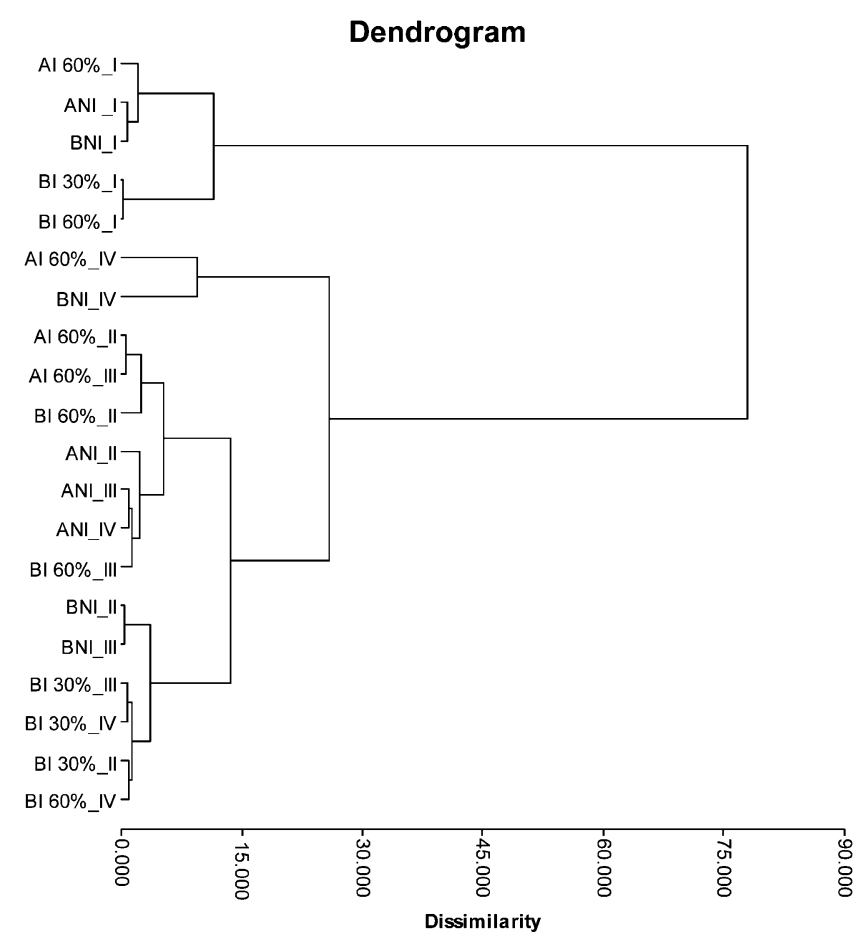

Figure 2. Dendogram of the carotenoid contents with different regimes of irrigation in the two analyzed soils.

increase of ${ }^{\circ}$ Brix. The largest percentage decreases were observed for chlorophyll $a$, lutein, and $\beta$-carotene of $64-89$, $42-83$, and $44-80 \%$, respectively. Violaxanthin and luteoxanthin appeared only from $22 / 08$ and seem to have slightly increased during this period (Table 3). These results are in agreement with previous work where the presence of carotenoids in grape berries demonstrated that $\beta$-carotene and several xanthophylls are abundant before veraison, with decreasing levels during ripening. These decreases were less prominent during the maturation (3).

Berry growth was studied by measurement of the berry weight and ${ }^{\circ}$ Brix (Table 3). Is contributed to an increase of berry size and to higher sugar concentrations in both soils (A and B). The higher sugar accumulation noted in irrigated vines may be related to their higher photosynthetic activity as compared to water-stressed vines, prolonging the period of photosynthetic activity by slowing leaf senescence. This effect can contribute to a lower rate of sugar transport to the berries in nonirrigated vines (11). Furthermore, higher vegetative growth (I) results in higher pruning weights and higher leaf area index where irrigated vines are not exposed to heat stress as compared to nonirrigated vines, which suffer high temperatures (12).

Figure 2 shows the degree of correlation of carotenoid contents with different regimes of irrigation in the two different soils, while Figure 3 gives the factors scores (factor score plot 1-2 accounts for $83 \%$ of total variance) from the principal components study carried out with data from Table 3. From a detailed study of these figures, it can be concluded that (i) for the first stage of maturation (I_19/07) two different groups can be seen, a first group (ANI, AI 60\%, and BNI) and a second group (BI 30\% and BI 60\%), that follow different patterns of variation. Carotenoids found in nonirrigated and irrigated grapes in the higher water retention capacity soil (ANI and AI 60\%) were similar. Because carotenoids are in much higher levels in skins than pulp (17), this nonvariation could be explained by the fact of observed increases in pulp-skin ratios with Is. Carotenoids found in the nonirrigated grapes in the lower water
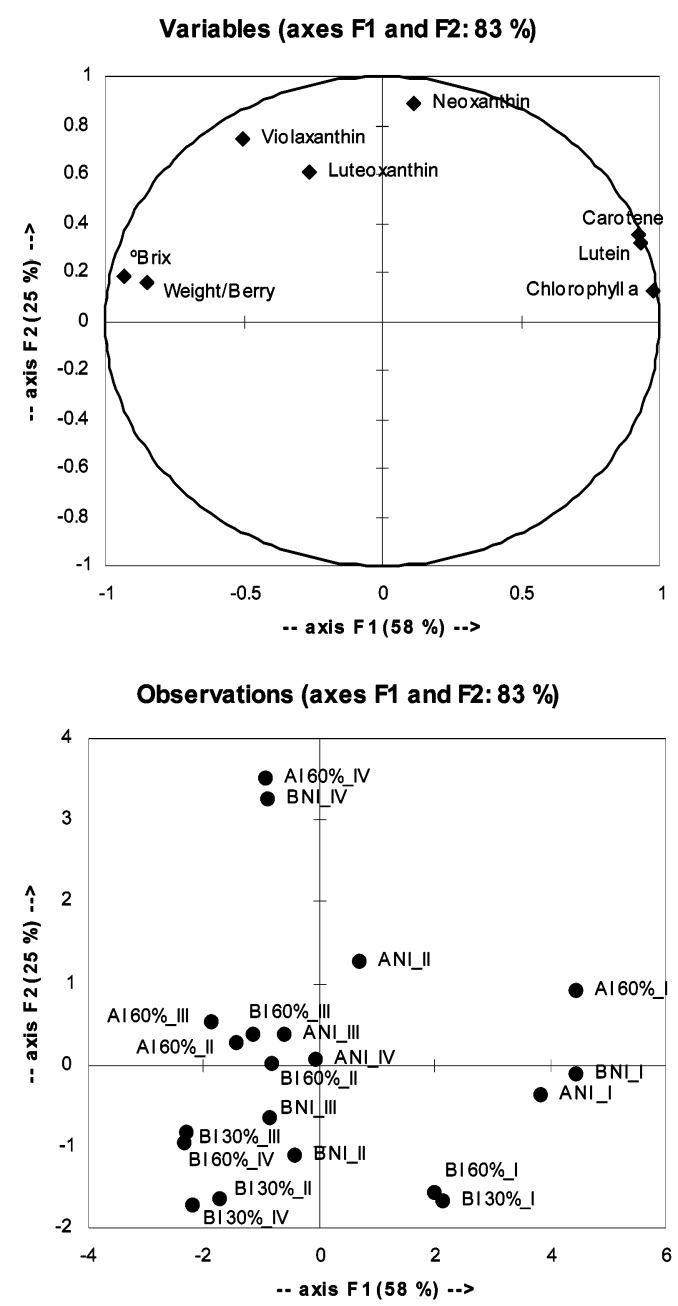

Figure 3. Principal components diagram of the carotenoid contents with different regimes of irrigation in the two analyzed soils. Factor score plot 1-2. Components 1 and 2 account for $83 \%$ of the total variance.

retention capacity soil (BNI) are close to those found in the higher water retention capacity soil (soil A). However, irrigation, in the lower water retention capacity soil (soil B), leads to a lower carotenoid concentration in the grapes. Nevertheless, different levels of irrigation, $30 \%$ and $60 \%$ of $\mathrm{ET}_{0}$, had similar values of carotenoids for BI $30 \%$ and BI $60 \%$, respectively. Carotenoid contents in irrigated grapes in the lower water retention soil (BI 60\%) were approximately 61 and $68 \%$ lower for lutein and $\beta$-carotene, respectively, than that of the nonirrigated grapes $(\mathrm{BNI})$.

(ii) For the last stage of maturation (IV_19/09), AI 60\% and $\mathrm{BNI}$ are well-grouped, indicating that carotenoid levels were similar for a nonirrigated lower water retention capacity soil (BNI) and an irrigated higher water retention capacity soil (AI $60 \%)$.

(iii) The other plots, which all exhibit different behaviors, are different from the others. For (II_22/08 and III_4/09) stages, Is, in soil B, are well-grouped, with the exception of the $60 \%$ of $\mathrm{ET}_{0}$ treatment. One these dates carotenoid decreasing, during ripeness, slowly down for this treatment. For soil A, the NI and I follows an identical variation in these stages of ripeness.

${ }^{\circ}$ Brix and berry weight are well-correlated. The correlation coefficient at the level of significance $\alpha=0.050$ (two-tailed test) is 0.853 . All carotenoids analyzed are well-correlated with ${ }^{\circ}$ Brix (correlation values higher than -0.6 reach -0.868 for 
chlorophyll $a$ ) with the exception of neoxanthin, violaxanthin, and luteoxanthin, which have different behaviors. Although ${ }^{\circ}$ Brix and berry weight increases were concomitant with I, no direct effect could be established between these parameters and carotenoid contents in grapes. Soil characteristics and water retention capacity affect canopy density and consequently bunch exposure to sunlight. Light has probably the largest effect on carotenoids content.

\section{CONCLUSION}

Soil and water retention capacity affect carotenoid contents in grapes. I seems to contribute to lower carotenoid levels in grapes, when vines are planted in a lower water retention capacity soil. This decrease was similar for both 30 and $60 \%$ of $\mathrm{ET}_{0}$. However, in a higher water retention capacity soil, I seems to have no effect in carotenoid contents when compared with NI.

It seems possible to produce grapes with higher weight and higher sugar levels together with similar carotenoid contents in an irrigated higher water retention capacity soil. It is reasonable to establish the possibility of improving wine production together with the eventual presence of substances with high aroma impact, knowing that carotenoids are precursors of several of these aroma compounds. On the other hand, soil characteristics had a larger influence than irrigation on the concentration of carotenoids in grapes, resulting in an important viticultural parameter to take into account in aroma precursor formation. To gather more information concerning other viticultural parameters that might help to better understand the results of the present work, ongoing research is under development.

\section{ABBREVIATIONS USED}

NI, nonirrigated treatment; I, irrigated treatment; $\mathrm{ET}_{0}$, potential evapotranspiration; $30 \%$ of $\mathrm{ET}_{0}, 30 \%$ of evapotranspiration; $60 \%$ of $\mathrm{ET}_{0}, 60 \%$ of evapotranspiration; ${ }^{\circ}$ Brix, total soluble solids; ANI, nonirrigated treatment in soil A; AI 60\%, irrigated treatment at $60 \%$ of evapotranspiration in soil A; BNI, nonirrigated treatment in soil B; BI 60\%, irrigated treatment at $60 \%$ of evapotranspiration in soil B; BI $30 \%$, irrigated treatment at $30 \%$ of evapotranspiration in soil B.

\section{LITERATURE CITED}

(1) Razungles, A.; Bayonove, C.; Cordonnier, R.; Baumes, R. Etude des caroténoides du raisin à maturité. Vitis 1987, 26, 183-191.

(2) Razungles, A.; Bayonove, C.; Cordonnier, R.; Sapis, J. Grape carotenoids: Changes during the maturation period and localization in mature berries. Am. J. Enol. Vitic. 1988, 39 (No. 1), 4448.

(3) Razungles, A.; Babic, I.; Sapis, J.; Bayonove, C. Particular behavior of epoxy xanthophylls during veraison and maturation of grape. J. Agric. Food Chem. 1996, 44, 3821-3825.

(4) Marais, J.; van Wyk, C.; Rapp, A. Carotenoid levels in maturing grapes as affected by climatic regions, sunlight and shade. $S$. Afr. J. Enol. Vitic. 1991, 12 (No. 2), 64-69.
(5) Bureau, S.; Razungles A.; Baumes, R.; Bayonove, C. Effect of vine or bunch shading on the carotenoid composition in Vitis Vinifera L. berries. I. Syrah grapes. Vitic. Enol. Sci. 1998, 53 (No. 2), 64-71.

(6) Razungles, A.; Bureau, S.; Bayonove, C.; Baumes, R. Effect de l'ensoleillement sur les teneurs en precurseurs d'aromes des baies de Syrah. OIV 1999, II, 382-388.

(7) Bureau, S.; Baumes, R.; Razungles, A. Effects of vine bunch shading on the glycosylated flavor precursors in grapes of Vitis Vinifera L. Cv. Syrah. J. Agric. Food Chem. 2000, 48, 12901297.

(8) Marais, J.; van Wyk, C.; Rapp, A. Carotenoids in grapes. Flavors and Off-Flavors; Proceedings of the 6th International Flavor Conference, Rethymnon, Crete, Greece, 5-7 July 1989.

(9) Kotseridis, Y.; Baumes, R.; Skouroumounis, G. K. Synthesis of labeled $\beta$-damascenone, 2 -methoxy-3-isobutylpyrazine, $\alpha$-ionone and $\beta$-ionone for quantification in grapes, juices and wines. $J$. Chromatogr. A 1998, 824, 71-78.

(10) Ruhl, E. H.; Alleweldt, G. Investigations into influence of time of irrigation on yield and quality of grapevines. Acta Hortic. 1985, 171, 457-462.

(11) Bartolomé, C. Respuestas de la vida ( $V$. vinifera $L$.) a condiciones de estres hídrico: efectos sobre las relaciones agua-planta, el crescimiento, la producción y la calidad (cv. Tempranillo). Tesis, Universidad Politécnica de Madrid, 1993.

(12) Esteban, M. A.; Villanueva, M. J.; Lissarrague, J. R. Effect of irrigation on changes in berry composition of Tempranillo during maturation. Sugars, organic acids and mineral elements. Am. J. Enol. Vitic. 1999, 50 (No. 4), 418-434.

(13) Ojeda, H.; Deloire, A.; Carbonneau, A. Influence of water deficits on grape berry growth Vitis 2001, 40 (3), 141-145.

(14) Deloire, A.; Carbonneu, A.; Federspilel, B.; Ojeda, H.; Wang, Z.; Costanza, P. La vigne et léau. Prog. Agric. Vitic. 2003, 120 (No. 4), 79-90.

(15) Lopes, C.; Vicente-Paulo, J.; Santos. T.; Rodrigues, M. L.; Barroso, J.; Chaves, M. M. An Attempt to Quantify Grapevine Water Stress in a Mediterranean Environment; 11th Meeting GESCO, University Degli Studi di Palermo, Palermo, Italy, 1999; pp 211-217.

(16) Escalona, J. M.; Flexas, J.; Schultz, H. R.; Medrano, H. Effect of moderate irrigation on aroma potential and other markers of grape quality. Acta Hortic. 1999, 493, 261-268.

(17) Allen, R.; et al. Crop evapotranspiration-Guidelines for computing crop water requirements; FAO Irrigation and Drainage Paper 56; FAO: Rome, 1998.

(18) Guedes de Pinho, P.; Ferreira, A. C.; Mendes Pinto, M.; Gomez Benitez, J.; Hogg, T. Determination of carotenoid profiles in grapes, musts and fortified wines from Douro varieties of Vitis vinifera. J. Agric. Food Chem. 2001, 49 (11), 5484-5488.

Received for review March 20, 2003. Revised manuscript received July 25, 2003. Accepted August 3, 2003. This work was supported by the Portuguese Ministry of Agriculture through the AGRO program (Project 313).

JF034275K 